\title{
A new era for the International CCN Society
}

\section{B. Perbal}

Published online: 8 February 2013

(C) The International CCN Society 2013

As the President of the International CCN Society, it is always a pleasure to write an Editorial that salutes all those who actively participated in the scientific expansion and recognition of our Society. The editorial will announce several important future changes and good news!

First of all, this Editorial affords me the opportunity to wish you all a very prosperous new year, and much professional success and personal satisfaction. Let us not forget to acknowledge our relatives for their constant support and understanding in the difficult times that we, as scientists may sometimes face in our daily pursuit of the keys to progress that could benefit humanity.

On a more practical note, I am delighted to report this year again that the official communication organ of the International CCN Society, the Journal of Cell Communication and Signaling, has seen its audience increase significantly, and according to SCImago figures, now ranks between the European Journal of Cell Biology, and FEBS Journal, with an average of 3,420 citations per citable items !

These metrics not only reflect the growing interest of scientists working on Cell Communication and Signaling, a field in which we have pioneered publications, but they also stem from the strong commitment of our Editors and authors who are dedicated to the success of this Journal.

The financial difficulties that research laboratories faced during 2012, as the result of uncertain economic situations, have had unfortunate consequences on scientific meetings worldwide. The number of colleagues who have had to turn down our invitation, due to financial problems, was such that led to the decision, like several other non profit organizations last year, to postpone the workshop that we had planned in Sydney.

The 7th Workshop is now scheduled to be held in Ann Arbor, Michigan in October 2013 (see below).

B. Perbal $(\bowtie)$

ICCNS, Paris, France

e-mail: bperbal@gmail.com

\section{The Sydney symposium}

In spite of the postponement of the CCN Workshop, Professor Stephen Twigg and myself decided to maintain the momentum and organize, at the University of Sydney, a symposium aimed at presenting and discussing overlapping interests of scientists working in the fields of IGF Binding Proteins and CCN Proteins.

The reason for choosing this topic stemmed from the partial identity between these two classes of proteins that was uncovered after the first three $\mathrm{CCN}$ genes were discovered. Nucleotide sequencing had shown that the N-terminus of the CCN proteins was structurally related to that of IGFBPs, but it was also determined that consideration of $\mathrm{CCN}$ proteins as IGFBP-related proteins was not appropriate.

The structural relationship between CCN and IGF binding proteins suggests that these two classes of proteins act along the same types of signaling pathways, as largely discussed in the Sydney Symposium.

Aside from these aspects, the Symposium provided the ground for fruitful interactions between scientists from the two fields, with major presentations by Professor Rob Baxter who discussed new functions of IGF binding proteins, Professor Bernard Perbal who reviewed the biological functions of $\mathrm{CCN}$ proteins and introduced the concept of $\mathrm{CCN}$ standing for Centralized Communication Network, Professor Takigawa who reviewed the functions of CCN2 in bone and cartilage, and Professor Andrew Leask who discussed new insights into the roles of $\mathrm{CCN}$ proteins in connective tissues. A meeting report will appear shortly in JCCS.

On the occasion of the Sydney Symposium, Professor R. Baxter received the third ICCNS-Springer Award in recognition of his scientific merit and contribution to the field of IGF binding proteins and IGF signaling. The Sydney Symposium also provided the opportunity to honor three members of the ICCNS, after they were selected by the Scientific Committee of the ICCNS. The ICCNS Award was presented to Professor B. Perbal for his substantial contributions to both the scientific and administrative aspects of the Society. 
The ICCNS Scientific Award was presented to Professor M. Takigawa for his consistently high level of meritorious achievements in the CCN field, and the ICCNS Research Promotion Award was presented to Professor S. Kubota for his scientific achievements of high merit in the CCN field.

\section{3 : a year for new changes}

Changes brought forward to our Society are the sign of a healthy scientific community, open to criticism, suggestions and challenges. Please feel free to contact us and discuss with us ICCNS-related matters. As the President of the ICCNS I have proposed to introduce the following modifications:

\section{Memberships}

In order to stimulate interactions with other scientists working on biological processes that are overlaping or closely related to those in which CCN proteins are major players, the ICCNS membership is now made freely available at no cost to all those who are interested in the biological functions of the $\mathrm{CCN}$ family of proteins and related partners in fields dealing with Cell Communication and Signaling. These regular members will now have free access to the Journal of Cell Communication and Signaling, the official journal of the ICCNS, receive news from the ICCNS, are encouraged to initiate scientific discussions on the ICCNS web site, have access to the $\mathrm{CCN}$-endorsed reagents that are made available from $\mathrm{CCN}$ specialists, and are invited to actively participate in the ICCNS sponsored meetings and Workshops.

In addition to these « regular members » the CCN Society also comprises Gold, Silver, Platinum and Honorary Members.

Silver members in addition to the benefits offered to Regular Members, are offered free publication of color figures in their JCCS published manuscripts. Silver Members can sponsor students and/or post docs applications to the Springer Scholarships offered at each International CCN Workshop.

Gold members have the same advantages as the Silver members and they now will have the option to pay a 2-years subscription at a reduced rate. Payment of the reduced fees for this 2 year period will also include a substantial reduction to the ICCNS-sponsored meetings and CCN workshop.

Platinum members in addition to the benefits offered to the Gold Members, qualify for application to serve as a Member on the JCCS Editorial Board. Decision is taken by the Executive Board after consultation with the Editor in Chief of JCCS, the President of the ICCNS scientific Committee, and the President of the ICCNS. Applications must be sent to the Executive Editor of JCCS. Platinum Members are requested to pay the Gold Member fees and make a donation to the ICCNS.

Honorary members are invited by the President of the ICCNS, on the basis of their outstanding scientific contributions (http:// www.ccnsociety.com/about_the_iccns/index.html). As a token of our deep appreciation of their outstanding scientific achievements, I have proposed, on behalf of the ICCNS, to invite the three recipients of the ICCNS-Springer awards (http:// www.ccnsociety.com/springer_award/index.html) to become honorary members of the International CCN Society. We are honored that they all have accepted our invitation.

\section{Joint International CCN Workshops and ICCNS- sponsored meetings}

In the continuation of the efforts put forward to stimulate the reunion of scientists interested in overlaping fields, I have extended this year our previous ICCNS-sponsored meeting experience (http:// www.ccnsociety.com/editorial/index.html) and have proposed that our next CCN Workshops be joined with an ICCNS-sponsored meeting dealing with a topic of direct interest for groups working on $\mathrm{CCN}$ proteins. Of course the expected beneficial effects will go both ways, as we also anticipate that the scientists who work in the other fields, will learn about $\mathrm{CCN}$ protein biology directly from leaders in the CCN field, and thereby be in a position to initiate fruitful collaborative projects.

This year Professor Gary Fisher at the University of Michigan, Ann Arbor, USA, accepted to organize with us a joint meeting whose topic will be " Advances in Fibrosis Research ». The 7th CCN workshop will be held in continuation of the fibrosis meeting, both of them having a considerable scientific overlap.

The next meeting that will be coupled with the 8th CCN Workshop is planed to cover « Advances in Inflammation Research », another exciting field!

We do hope that this experience will be a success and we count on all of you to advertize this meeting. The practical aspects of the joint meeting will be posted and updated regularly on the ICCNS web site (http://ccnsociety.com).

Other topics of interest have already been identified as good matching candidates for future meetings of this type. Information will be posted shortly on the ICCNS website.

We believe that the changes introduced this coming year should boost our expanding Society and should promote scientific communication between « scientific neighbors ».

Again on behalf of the ICCNS I wish you all a wonderful new year and look forward to meeting you soon!

Professor Bernard Perbal

Executive Editor of JCCS

President of the International CCN Society

January 20th, 2013 